\title{
Terminal investment induced by a bacteriophage in a
}

\section{rhizosphere bacterium [version 1; peer review: 2 approved}

\section{with reservations]}

\section{Timothée Poisot ${ }^{1-3}$, Thomas Bell4 ${ }^{4}$ Esteban Martinez ${ }^{1}$, Claire Gougat-Barbera1, Michael E Hochberg ${ }^{1,5}$}

\author{
${ }^{1}$ Université Montpellier II, Institut des Sciences de l'Evolution, Montpellier, France \\ 2Département de biologie, chimie et géographie, Université du Québec à Rimouski, Rimouski, QC, G5L 3A1, Canada \\ ${ }^{3}$ Québec Centre for Biodiversity Sciences, Stewart Biological Sciences Building, Montréal, QC, H3A 1B1, Canada \\ ${ }^{4}$ Department of Life Sciences, Imperial College London, Silwood Park Campus, Ascot, Berkshire, SL5 7PY, UK \\ ${ }^{5}$ Santa Fe Institute, Santa Fe, NM, 87501, USA
}

\section{V1 First published: 02 Oct 2012, 1:21 \\ https://doi.org/10.12688/f1000research.1-21.v1}

Latest published: 20 May 2013, 1:21

https://doi.org/10.12688/f1000research.1-21.v2

\section{Abstract}

Despite knowledge about microbial responses to abiotic stress, few studies have investigated stress responses to antagonistic species, such as competitors, predators and pathogens. While it is often assumed that interacting populations of bacteria and phage will coevolve resistance and exploitation strategies, an alternative is that individual bacteria tolerate or evade phage predation through inducible responses to phage presence. Using the microbial model Pseudomonas fluorescens SBW25 and its lytic DNA phage SBW25Ф2, we demonstrate the existence of an inducible response in the form of a transient increase in population growth rate, and found that the response was induced by phage binding. This response was accompanied by a decrease in bacterial cell size, which we propose to be an associated cost. We discuss these results in the context of bacterial ecology and phage-bacteria co-evolution.

Keywords

stress / inducible response / Pseudomonas fluorescens / bacteriophages

\begin{tabular}{l} 
Open Peer Review \\
Approval Status \\
\hline version 2 \\
(update)
\end{tabular}

1. Britt Koskella, University of Exeter, Exeter, UK

2. Paul E. Turner, Yale University, New Haven, CT, USA

Any reports and responses or comments on the article can be found at the end of the article. 
Corresponding author: Timothée Poisot (timothee_poisot@uqar.ca)

Competing interests: No competing interests were disclosed.

Grant information: TP is funded by a CNRS-Région Languedoc Roussillon doctoral grant. TB was funded by NERC. MEH is funded by ANR EvolStress (ANR-09-BLAN-099-01), by the Ec2Co "Cytrix" program, and the McDonnell Foundation (JSMF 220020294/SCS-Research Award).

The funders had no role in study design, data collection and analysis, decision to publish, or preparation of the manuscript.

Copyright: @ 2012 Poisot T et al. This is an open access article distributed under the terms of the Creative Commons Attribution License, which permits unrestricted use, distribution, and reproduction in any medium, provided the original work is properly cited. Data associated with the article are available under the terms of the Creative Commons Zero "No rights reserved" data waiver (CCO 1.0 Public domain dedication).

How to cite this article: Poisot T, Bell T, Martinez E et al. Terminal investment induced by a bacteriophage in a rhizosphere bacterium [version 1; peer review: 2 approved with reservations] F1000Research 2012, 1:21

https://doi.org/10.12688/f1000research.1-21.v1

First published: 02 Oct 2012, 1:21 https://doi.org/10.12688/f1000research.1-21.v1 


\section{Introduction}

Pathogens are ubiquitous in natural communities ${ }^{1}$ and the antagonistic interactions they establish with their hosts are recognized as one of the main drivers of evolutionary diversification ${ }^{2,3}$. Hosts can reduce the impact of pathogens through three non-mutually exclusive processes $^{4}$ : (i) avoidance of either infected individuals, habitats where the pathogen is prevalent, or of the pathogen itself $^{5}$, (ii) resistance to the actual infection process or post-infection immune defences $^{6}$, and (iii) tolerance ${ }^{7}$. Research on these responses has generally focused on animal and plant models, but there is growing appreciation that microbes, particularly bacteria, can exhibit similar responses. For instance, bacteria can be selected for heightened levels of genetic resistance towards infection by pathogens ${ }^{8-10}$. On the other hand, although bacteria are known to display plastic responses to various types of environmental stresses ${ }^{11,12}$ and to competition $^{13}$, it is unknown whether they can do so when faced with natural enemies such as bacteriophages.

Plastic responses are an adaptive phenotypic change following an environmental stimulus, occurring without a concurrent change in the genotype ${ }^{14}$. They may involve behavioural, physiological or phenological changes ${ }^{15,16}$, and be triggered by direct or indirect contact with the stimulus ${ }^{17}$ or through communication with neighbouring organisms ${ }^{18}$. Phenotypic plasticity is considered to be a genetic adaptation to variable environments, but given the diversity of associated mechanisms and behaviours, it is not known to what extent different stimuli translate into different responses ${ }^{15,19}$.

Individual-level interactions between bacteria and phage may be conducive to induced responses. The first step of bacteriophage infection is the binding of phage proteins to bacterial surface proteins ${ }^{20}$, which then triggers conformational changes to both proteins ${ }^{21}$. Surface proteins used by the bacterium for signal transduction are known to be targets of bacteriophage adsorption ${ }^{22}$ and as such could trigger a response when bacteriophage binding is detected. Such a response would allow a bacterium to react to the pathogen and to eventually either evade or reduce the effects of the infection. Lytic phages are prime candidates for organisms against which bacteria may have evolved a stress response, because they typically interact with their host over short timescales, and death is inevitable once the phage has injected its DNA into a sensitive bacterial cell.

In addition, bacteriophages are widely distributed in the environment $^{20}$ and interact with their hosts over relatively small spatial scales $^{23}$ and throughout most of the year ${ }^{24,25}$. This could select for the expression of induced structural, physiological or behavioural responses to different enemies. Also, bacteria employ signalling pathways and have a known ability to communicate within populations ${ }^{26}$. Such pathways could induce and synchronise inducible responses before predators and pathogens are encountered, or at least before they have spread through the population, or before the point beyond which cell death is certain. All of these factors suggest that plastic stress responses to phage should be a common feature of bacterial cells and that such responses would have important repercussions for ecological and evolutionary interactions between phage and bacterial populations. Although molecular responses of bacteria to bacteriophages have been characterized ${ }^{27}$, the behavioral, ecological, and selective consequences of such responses are not known.

Here we demonstrate that when confronted with phage, bacteria express transient increases in division rate at a cost to individual biomass accumulation ${ }^{28}$. Specifically, we employ the rhizosphere bacterium Pseudomonas fluorescens SBW $25^{29}$ to investigate how its population growth rate is affected by exposure to inactivated populations of is lytic bacteriophage SBW25 $\Phi 2^{30}$. We find that bacteria exposed to inactivated phage increase their fission rate nearly two-fold at 24 hours post-exposure. This is followed by a continual decrease in fission rate relative to the control. We also show that bacteria exposed to inactivated phage were smaller in size compared to controls. All of these effects were enhanced as the density of inactivated phage was increased. The results are consistent with a behavioural strategy that increases allocation to reproduction under stressful conditions (i.e., "terminal investment"). Terminal investment is well characterised for other host-parasite associations ${ }^{31}$, but to our knowledge has not previously been observed in bacteria and phage.

\section{Results}

Bacteria exposed to UV-inactivated phage display a statistically significant higher growth rate over the first 24 hours post-exposure than non-phage controls (Kruskal-Wallis, $\mathrm{df}=3, \mathrm{P}=0.006$; Figure 1). After this period, the estimated doubling time of exposed bacteria increased (i.e., their populations grew slower), and did so for the next 48 hours. This decrease in growth rate compared to controls is suggestive of a cost to the higher fission rate observed over the first

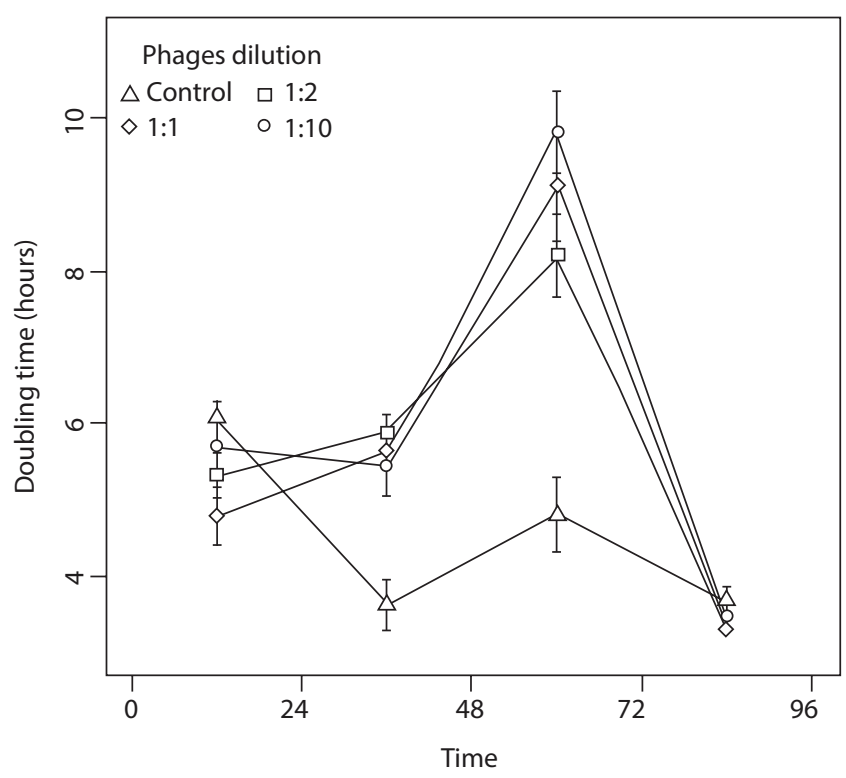

Figure 1. Maximum doubling time (in hours) of biomass produced by bacteria exposed to different concentrations of UV-inactivated phage. This was measured for four consecutive days following four hours exposure. Bacteria exposed to phage grew significantly faster than controls over the first day, and then expressed an apparent cost in terms of smaller cell size that attenuated by the fourth day. Central points are the means of 12 replicates, and the bars are standard errors. 
24 hours (Figure 1). During the fourth day post-exposure, control and treatment bacteria showed no significant differences in doubling time $(\mathrm{KW}, \mathrm{df}=3, \mathrm{P}>0.05)$. That exposed bacteria returned to their ancestral growth rate suggests that the response over the first 24 hours was due to phenotypic plasticity and not selection on faster growing genotypes. There was a marginally significant effect on population growth for bacteria exposed to different phage concentrations $(\mathrm{KW}, \mathrm{df}=2, \mathrm{P}<0.02)$, suggesting that the encounter rate between bacteria and phage is important in determining the population-level strength of the fission response.

\section{Bacterial doubling time, expressed in hours, as a function of the treatment}

1 Data File

http://dx.doi.org/10.6084/m9.figshare.95948

We hypothesized that faster doubling times would come at a cost to cell size, since cells would have less time to metabolize and convert absorbed nutrients into cell structure Twenty-four hours postexposure, we found that phage-treated bacteria were two to three times smaller (as measured by mean cellular width) than the control $(\mathrm{KW}, \mathrm{df}=3, \mathrm{P}<0.0001$; Figure 2). This difference in size gradually decreased over the following 3 days, but in contrast to growth rate (Figure 1), bacteria did not attain their ancestral cell size by the end of the experiment (Figure 2). Analyses of the distribution of several flow cytometry profiles showed that a difference in cell shape is unlikely to explain this result (see data associated to this article). Finally, observations using a transmission electron microscope showed that the cells remained rod-shaped for all treatments.

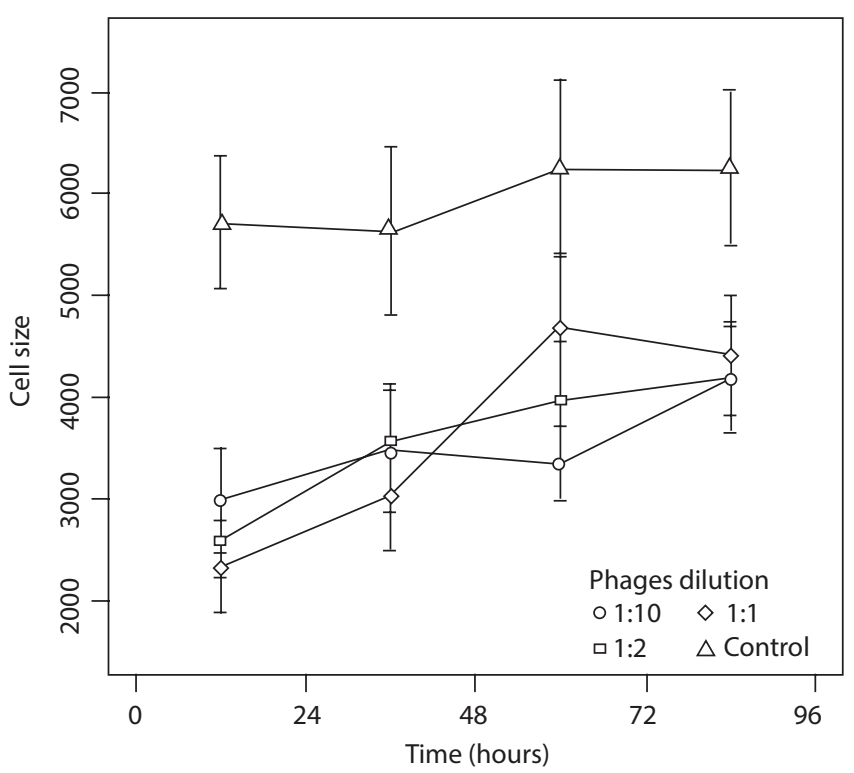

Figure 2. Mean bacterial cell size (forward scatter parameter) exposed to different concentrations of UV-inactivated phage, as per the method in Figure 1. Bacteria exposed to phage at different concentrations do not significantly differ in size. Points and bars are the same as in Figure 1.

\section{Raw flow cytometry data}

1 Data File

http://dx.doi.org/10.6084/m9.figshare.95949

We did not observe any difference in the impact of live phage on bacterial populations exposed to the different treatments $(\mathrm{KW}, \mathrm{df}=2$, $\mathrm{P}=0.153$ ), suggesting that the inducible response does not alter bacteria resistance to phage predation.

\section{Discussion}

Our experiments reveal a previously unexplored behavioural response to bacteriophage predation: phage induce bacteria to reproduce earlier in their cell cycle. We hypothesize that this response increases the survival chances of progeny under natural conditions and demonstrate that this behaviour comes at a fitness cost of reduced size of daughter cells. Our experiments with UV-inactivated phage further demonstrate that this response is specifically due to phage binding.

These results support and extend both theoretical ${ }^{32}$ and empirical ${ }^{33,34}$ predictions that victims may lessen the fitness impact of their natural enemies through early reproduction, to cases where phenotypic responses are plastic and temporary. Increased allocation to reproduction in stressful environments-termed "fecundity compensation" or "terminal investment" 31 - although never studied in bacteriaphage associations to our knowledge - has been extensively studied for other host-parasite (or organism - stressor) interactions. Terminal investment is characterized by increased reproductive rate or the earlier onset of reproduction, if the prospect of future reproduction is low $^{35}$. Examples of such responses include faster host maturation ${ }^{36}$, increased oviposition rate ${ }^{37}$, and the modification of traits involved in the onset of reproduction ${ }^{38,39}$.

Phenotypically plastic responses are important in that they allow individuals to cope with environmental change during their lifetimes $^{40}$. As such, plasticity is expected to be favoured in variable environments when the costs of induction and phenotypic change compensate for probabilistic (expected) fitness loss ${ }^{41}$. Although it is difficult to generalize about constitutive costs of resistance across biological systems ${ }^{42,43}$, limited evidence suggests that genetically evolved, constitutive resistance in bacteria to their lytic phage could have costs of as much as $5-10 \%$ to relative fitness ${ }^{44}$.

We employed inactivated bacteriophages to evaluate how phage contact with the bacterial outer membrane mediates bacterial responses. Bacteria could be selected to exhibit an escape response in several, non-mutually exclusive ways. First, non-virulent phage may signal the presence of virulent phage in the local environment (i.e., the bacterium does not perish following initial phage contact). Senescent (inactive) phage are present in natural environments ${ }^{25}$, and many phages bind to outer membrane proteins without being infective (e.g. the bacterium is resistant; ${ }^{44}$ ). Moreover, it is possible that phage could detach if they sense the host to be unsuitable ${ }^{45}$. Second, when phage infect the bacterium there may be a 'race' between the time it takes a bacterial cell to divide (and potentially survive) and the point of no recovery associated with the maturation of phage progeny and bacterial cell lysis. Third, the response 
may be a consequence of lysogens competing with lytic phages for host exploitation; the latter could benefit from early host reproduction in the presence of lytic competitors. However, sequencing of the P. fluorescens SBW25 genome revealed a low abundance of prophage-like regions ${ }^{46}$.

We were not able to determine whether the bacteria or the phage benefit from faster bacterial reproduction, and the literature reports effects both of facilitation and decrease in host metabolism upon infection ${ }^{47}$. Previous theoretical work suggests that phage productivity increases in bacteria with short life-cycles ${ }^{48}$. This is supported by recent empirical study employing the same strain of $P$. fluorescens ${ }^{49}$. Assuming that the physiological mechanisms involved in fission rate increases are the same in the two experiments, this suggests that rapid multiplication is not adaptive for the bacterium. Upon exposure to phage, bacteria reproduce faster, but experience a persistent reduction in individual size. Smaller cells have less surface area, and assuming that the density of receptor proteins does not change with cell size, this suggests that they will have lower encounter rates with phage. One possibility is that cell division allows bacterial cells to concentrate phage in one of the daughter cells ${ }^{50,51}$, resulting in some progeny managing to escape the pathogen. Future studies should therefore focus on the possible adaptive nature of this response for both bacterium and phage.

\section{Methods}

\section{Bacteria cultures}

Ancestral Pseudomonas fluorescens SBW $25^{29}$ were inoculated into $30 \mathrm{ml}$ microcosms containing $6 \mathrm{~mL}$ of King's B medium (KB), and allowed to grow under alternating rotational agitation $(200 \mathrm{rpm}$ for 1 minute every 30 minutes). Every $48 \mathrm{~h}$ following plating on solid agar, $10 \mathrm{CFU}$ of the smooth morphotype were transferred into fresh KB medium. After 10 transfers, the culture was composed of smooth morphotypes only. We continued this selection procedure for another 10 transfers and then arbitrarily isolated a single CFU, which was used for all experiments described below. Experiments were conducted at $28^{\circ} \mathrm{C}$ in $\mathrm{KB}$ medium under constant rotational agitation (200 rpm).

\section{Phage cultures}

We grew an arbitrarily selected clone of the ancestral phage SBW25Ф $2^{30}$ on an exponentially growing culture of fixed smooth P. fluorescens SBW25 in $3 \mathrm{~mL}$ of $\mathrm{KB}$ for 48 hours. This resulted in a culture containing approximately $10^{8}$ phage per ml. The sample was then centrifuged for 3 minutes at $8000 \mathrm{rpm}$ in a $1.5 \mathrm{ml}$ Eppendorf tube, and the pellet discarded. Centrifugation was repeated three times to ensure all bacteria were removed (see Supplement Figure 1). Phages were then isolated by centrifuging the remaining supernatant for 8 minutes at $13000 \mathrm{rpm}$, and inoculating the pellet into fresh $\mathrm{KB}$ medium. The sample was thoroughly vortexed and exposed to UV light (Model 4.LC, Vilber Lourmat, Deutschland, $254 \mathrm{~nm}$ wavelength) at $5 \mathrm{~cm}$ distance for 4 hours. Extensive pilot studies demonstrated that this method was sufficient to kill all phage (see Supplement Figure 2).
Preliminary tests

We conducted a series of preliminary tests to verify how UVinactivated phage affected bacterial hosts. First, observations under a transmission electron microscope showed that UV-inactivated phage were still intact and able to bind to their bacterial hosts. Second, we checked that bound UV-inactivated phage did not introduce phage DNA into the bacteria. This was done by inoculating $1 \mathrm{ml}$ of UV-inactivated phage into 6 overnight bacterial cultures. Inactivated phage were allowed $4 \mathrm{~h}$ to attach to the bacterial outer membrane. We separated phage and bacterial fractions by filtration using a $0.2 \mu \mathrm{m}$ filter. We then conducted a full DNA extraction (WholeBlood NucleoSpin DNA extraction kit, Macherey-Nagel) of the filter. PCR was done using TPVIf (GATGTGAGAAAGCGATACACGG) and TPVIr (GAGAGAAGCGGGAGAGTGAA) sequences developed for this study, which selectively amplify a $550 \mathrm{bp}$ fragment of the phage DNA and a $1200 \mathrm{bp}$ fragment of the bacterial DNA (see Supplement Figure 1 for detailed protocols). We did not find any evidence that UV-inactivated phage was present in samples putatively containing bacteria only, thus confirming that the DNA of inactivated phage was not incorporated in the bacterial cell.

\section{Experiments using UV-inactivated phage}

We conducted an experiment to understand how UV-inactivated phage affected bacterial behaviour. Fixed smooth SBW25 bacteria were first cultivated in $6 \mathrm{ml} \mathrm{KB}$ in $30 \mathrm{~mL}$ universal glass vials. $20 \mu \mathrm{L}$ of exponentially growing bacteria ( $c 10^{4}$ bacterial cells) were transferred into fresh KB medium with either no phage or UV-inactivated phage at ratios of 1:10,1:2, and 1:1 (corresponding to approximately $10^{6}, 5 \times 10^{6}$, and $10^{7}$ phage per $\mathrm{ml}$ ), and then allowed to interact for 4 hours under alternating shaking ( $200 \mathrm{rpm}$ for 1 minute every 30 minutes). Bacteria were then separated from bound phage by centrifuging (see above) and placed in fresh $\mathrm{KB}$ medium. $1 \%$ of each population was transferred every 24 hours into new $\mathrm{KB}$ medium. Each of the 4 treatments was replicated 6 times and arranged arbitrarily in a rack for incubation.

\section{Measures}

Biomass doubling time (used as a proxy for population fitness) was measured in a Fluostar Optima spectrophotometer $\left(28^{\circ} \mathrm{C}\right.$, constant agitation, 250 measures at $650 \mathrm{~nm}$ over 24 hours) each day, using the following formula:

$$
\mathrm{D}_{\mathrm{t}}=[\Delta \mathrm{t} \ln (2)] /\left[\ln \left(\mathrm{N}^{*}\right)-\ln \left(\mathrm{N}_{0}\right)\right]
$$

where $\mathrm{N}^{*}$ and $\mathrm{N}_{0}$ are the total biomasses (measured as optical density, OD) before and after the exponential growth phase, and $\Delta t$ is the duration of the exponential phase. Exponential phase was determined by conducting a series of windowed linear regressions over the full growth curve, and retaining the part of the curve with the largest slope (computer code given in suppl. materials part 3).

Individual cell size was measured by flow-cytometry using a FacsCantoII (BD BioSciences, San Jose, California, USA), and data (forward scatter) were analysed using the flowCore package ${ }^{52}$ 
in $\mathrm{R} 2.12 .0^{53}$. Each measure was performed on a sample of $2 \times 10^{5}$ cells without dyes.

We also estimated the sensitivity of the different treatments to live phage by measuring changes in bacterial populations. At each 24-hour transfer, $1 \%$ of the bacterial population was placed in $2 \mathrm{~mL}$ of fresh $\mathrm{KB}$, and $20 \mu \mathrm{L}$ of amplified phage ( $\mathrm{ca} 10^{8}$ viral particles) were added (a control without phage was conducted simultaneously). Bacteria CFUs were counted on solid agar after 48 hours of incubation to estimate population size.

Due to non-normality of the data as assessed by a Shapiro test, we used a Kruskal-Wallis test to determine the significance of the between-treatments effects.

\section{Author contributions}

TP, TB and MEH designed the research, TP and EM conducted the microbiology experiments, TP and CGB conducted the molecular biology experiments, TP, TB and MEH analyzed the results and wrote the paper, all authors contributed to revisions.

\section{Competing interests}

No competing interests were disclosed.

\section{Grant information}

TP is funded by a CNRS-Région Languedoc Roussillon doctoral grant. TB was funded by NERC. MEH is funded by ANR EvolStress (ANR-09-BLAN-099-01), by the Ec2Co "Cytrix" program, and the McDonnell Foundation (JSMF 220020294/SCS-Research Award).

The funders had no role in study design, data collection and analysis, decision to publish, or preparation of the manuscript.

\section{Acknowledgments}

We are indebted to Cédric Mongellaz for his assistance with flow cytometry, and the Montpellier RIO Imaging center for providing technical support. We thank Michael Brockhurst and Angus Buckling for discussions.

\section{Supplementary material}

1. Molecular biology protocol and results

PCR cycle -6 minutes at $95^{\circ} \mathrm{C}$, then 30 cycles of 1 minute at $94^{\circ} \mathrm{C}$, 1 minute at $55^{\circ} \mathrm{C}, 2$ minutes at $72^{\circ} \mathrm{C}$, then 10 minutes at $72^{\circ} \mathrm{C}$.

PCR buffer $-5 \mu \mathrm{L}$ of buffer, $4 \mu \mathrm{L}$ of primers at $10 \mathrm{pM} / \mathrm{mL}$ (for both TPV1f and TPV1r), $2 \mu \mathrm{L}$ of dNTP at $5 \mathrm{pM} / \mathrm{mL}, 1.5 \mu \mathrm{L}$ of $\mathrm{MgCl} 2$ at $25 \mathrm{mM}, 5.35 \mu \mathrm{L}$ of $\mathrm{H} 20,3 \mu \mathrm{L}$ of sample DNA, $0.15 \mu \mathrm{L}$ of TaqPol conducted with a GoTaq FlexiDNA Polymerase M8301 kit from Promega.

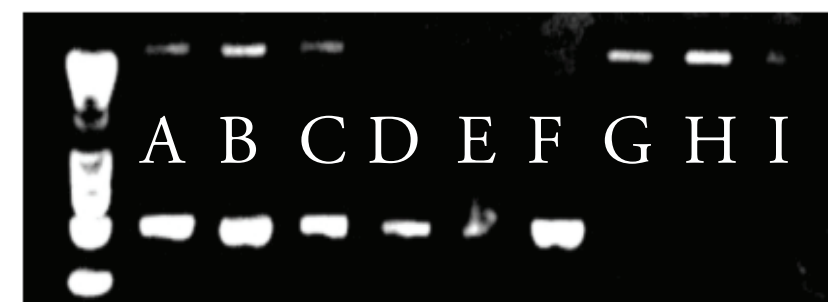

Supplementary Figure 1. Sample gel obtained on 9 total DNA extractions (A-C: bacteria and page, D-F: phage only, following extraction as explained in text, G-I: bacteria following exposure to inactivated phage, whose DNA was extracted after removal of inactivated phages). The primers TPV $1 f$ and TPV1r yield a $1200 \mathrm{bp}$ amplicon in the bacteria, and a $500 \mathrm{bp}$ amplicon in phages. Our seperation method for bacteria and phage was complete, since only DNA of the intended organism was found in any given sample.

\section{Preliminary experiments and phage}

We verified the efficiency of the phage inactivation protocol by incubating the bacterial strain used for the main experiment with either live phage or phage exposed to UV for $2 \mathrm{hrs}$ or $4 \mathrm{hrs}$. We measured the Malthusian fitness of 6 host populations near carrying capacity at low temperature $\left(4^{\circ} \mathrm{C}\right.$, growth restrictive $)$ over the course of $24 \mathrm{hrs}$ (the difference with the experiment presented in the main text is that inactivated phage were not removed over the course of this pilot study).

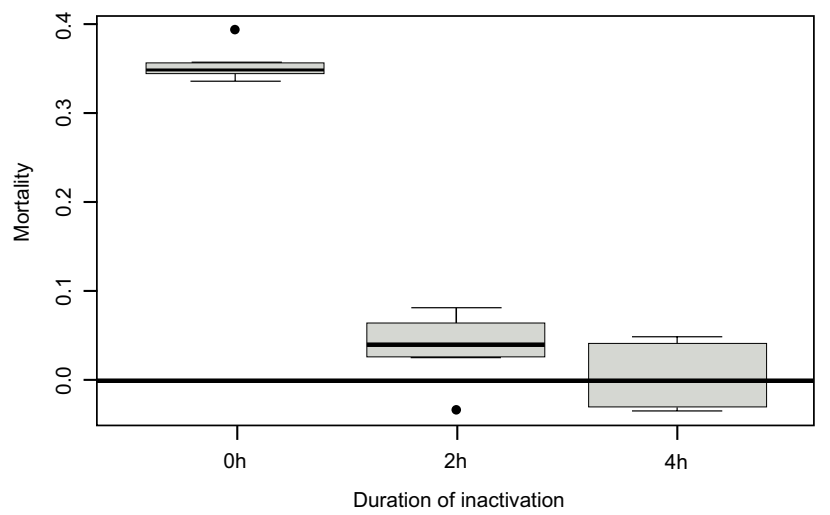

Supplementary Figure 2. Bacterial mortality as a function of phage inactivation. Because bacteria do not grow at $4^{\circ} \mathrm{C}$, we can directly measure phage-induced mortality. After 4 hours of exposure to UV, we observed that phages do not introduce significant mortality in the bacterial population. Kruksal-Wallis test ( $d f=2, p=0.02$ ) reveals differences between treatments, with 0 h and $2 \mathrm{~h}$ being significantly different (t-test, $\mathrm{df}=7, \mathrm{p}<10^{-5}$ ), $0 \mathrm{~h} / 4 \mathrm{~h}$ being significantly different (t-test, $\mathrm{df}=8, \mathrm{p}<10^{-5}$ ), and $2 \mathrm{~h}$ and $4 \mathrm{~h}$ being similar (t-test, $\mathrm{p}=0.16$ ) - all $\mathrm{p}$-values were Bonferronicorrected to account for multiple testing. Similarly, $2 \mathrm{~h}$ and $4 \mathrm{~h}$ are not significantly different from 0 ( $p$-values of $-5-50.14$ and 0.89 respectively, after correction) 
3. Determination of the maximal growth rate $(\mathrm{R}$ code) givegrowth $=$ function $(y, x=c(1$ :length $(y))$, $b w=12)$ \#\# y : optical density

\#\# $\mathrm{x}$ : times of the measures

\#\# bw : number of points to include in regression

\{

list.of.coeff- < NULL

for (i in 1:(length $(\mathrm{x})-\mathrm{bw}))\{$

part. $x<-x[i:(i+b w)]$ part.y $<-y[i:(i+b w)]$

cur. $\operatorname{lm}<-\operatorname{lm}($ part.y $\sim$ part.x)\$coeff[2]

list.of.coeff $[\mathrm{i}]<-$ cur.lm

\}

result $<-\max ($ list.of.coeff $)$

$\operatorname{pos}<-\operatorname{match}(\max ($ list.of.coeff), list.of.coeff)

coeff $<-\operatorname{lm}($ y[pos: $($ pos + bw $)] \sim$ x $[$ pos: $($ pos + bw) $]) \$ c o e f f$

return(as.numeric(coeff[2]))
1. Lafferty KD, Dobson AP, Kuris AM: Parasites dominate food web links. Proc Natl Acad Sci U S A. 2006; 103(30): 11211-6.

PubMed Abstract | Publisher Full Text | Free Full Text

2. Coberly LC, Wei W, Sampson KY, et al:: Space, time, and host evolution facilitate coexistence of competing bacteriophages: theory and experiment. Am Nat. 2009; 173(4): E121-38.

PubMed Abstract | Publisher Full Text | Free Full Text

3. Weitz JS, Hartman H, Levin SA: Coevolutionary arms races between bacteria and bacteriophage. Proc Natl Acad Sci U S A. 2005; 102(27): 9535-40. PubMed Abstract | Publisher Full Text | Free Full Text

4. Boots M, Bowers RG: Three mechanisms of host resistance to microparasitesavoidance, recovery and tolerance-show different evolutionary dynamics. $J$ Theor Biol. 1999; 201(1): 13-23.

PubMed Abstract | Publisher Full Text

5. Hart BL: Behavioral adaptations to pathogens and parasites: five strategies. Neurosci Biobehav Rev. 1990; 14(3): 273-294.

PubMed Abstract | Publisher Full Text

6. Ebisuzaki K, Jellie SB: Postinfection control in T4 bacteriophage infection: inhibition of the rep function. $J$ Virol. $1981 ; 37(3)$ : 893-8. PubMed Abstract | Free Full Text

7. Miller MR, White A, Boots M: The evolution of host resistance: tolerance and control as distinct strategies. J Theor Biol. 2005; 236(2): 198-207.

PubMed Abstract | Publisher Full Text

8. Forde SE, Beardmore RE, Gudelj I, et al.: Understanding the limits to generalizability of experimental evolutionary models. Nature. 2008; 455(7210): 220-223.

PubMed Abstract | Publisher Full Text

9. Gruner DS, Kolekar A, McLaughlin JP, et al.: Host resistance reverses the outcome of competition between microparasites. Ecology 2009; 90(7): 1721-1728.

PubMed Abstract | Publisher Full Text

10. Poullain V, Gandon S, Brockhurst MA, et al:: The evolution of specificity in evolving and coevolving antagonistic interactions between a bacteria and its phage. Evolution. 2008; 62(1): 1-11. PubMed Abstract | Publisher Full Text

11. Storz GT, Hengge-Aronis R: Bacterial Stress Responses. ASM Press. 2000. Reference Source

12. Wang S, Deng K, Zaremba S, et al.: Transcriptomic response of Escherichia coli O157:H7 to oxidative stress. Appl Environ Microbiol. 2009; 75(19): 6110-23. PubMed Abstract | Publisher Full Text | Free Full Text

13. Kümmerli R, Jiricny N, Clarke LS, et al.: Phenotypic plasticity of a cooperative behaviour in bacteria. J Evol Biol. 2009; 22(3): 589-98. PubMed Abstract | Publisher Full Text

14. Schlichting $C D$, Pigliucci M: Phenotypic evolution: a reaction norm perspective Sinauer Associates Sunderland, MA. 1998; 387.

Publisher Full Text

15. Frank SA: A model of inducible defense. Evolution. 1993; 47(1): 325-327. Reference Source

16. Schlichting CD: The evolution of phenotypic plasticity in plants. Annu Rev Ecol Syst. 1986; 17: 667-693. Publisher Full Text

17. Maleck K, Dietrich RA: Defense on multiple fronts: how do plants cope with diverse enemies? Trends Plant Sci. 1999; 4(6): 215-219. PubMed Abstract | Publisher Full Text

18. Shapiro JA: Bacteria are small but not stupid: cognition, natural genetic engineering and socio-bacteriology. Stud Hist Philos Biol Biomed Sci. 2007; 38(4): 807-819.

PubMed Abstract | Publisher Full Text
19. Stanton ML, Roy BA, Thiede DA: Evolution in stressful environments. I. Phenotypic variability, phenotypic selection, and response to selection in five distinct environmental stresses. Evolution. 2000; 54(1): 93-111. PubMed Abstract | Publisher Full Text

20. Abedon ST: Bacteriophage Ecology: Population Growth, Evolution, and Impact of Bacterial Viruses. Cambridge University Press. 2008; 85(1): 526. Publisher Full Text

21. Ossiboff RJ, Zhou Y, Lightfoot PJ, et al:: Conformational changes in the capsid of a calicivirus upon interaction with its functional receptor. $J$ Virol. 2010; 84(11): 5550-64.

PubMed Abstract | Publisher Full Text | Free Full Text

22. Menge DN, Weitz JS: Dangerous nutrients: evolution of phytoplankton resource uptake subject to virus attack. J Theor Biol. 2009; 257(1): 104-115. PubMed Abstract | Publisher Full Text

23. Vos M, Birkett PJ, Birch E, et al.: Local adaptation of bacteriophages to their bacterial hosts in soil. Science. 2009; 325(5942): 833. PubMed Abstract | Publisher Full Text

24. Ashelford KE, Norris SJ, Fry JC, et al:: Seasonal population dynamics and interactions of competing bacteriophages and their host in the rhizosphere. Appl Environ Microbiol. 2000; 66(10): 4193-4199.

PubMed Abstract | Publisher Full Text | Free Full Text

25. Maurice CF, Bouvier T, Comte J, et al.: Seasonal variations of phage life strategies and bacterial physiological states in three northern temperate lakes. Environ Microbiol. 2010; 12(3): 628-41. PubMed Abstract | Publisher Full Text

26. Waters CM, Bassler BL: Quorum sensing: cell-to-cell communication in bacteria. Annu Rev Cell Dev Biol. 2005; 21: 319-346. PubMed Abstract | Publisher Full Text

27. Huvet $\mathrm{M}$, Toni $\mathrm{T}$, Sheng $\mathrm{X}$, et al.: The evolution of the phage shock protein response system: interplay between protein function, genomic organization, and system function. Mol Biol Evol. 2011; 28(3): 1141-1155. PubMed Abstract | Publisher Full Text | Free Full Text

28. St-Pierre F, Endy D: Determination of cell fate selection during phage lambda infection. Proc Natl Acad Sci U S A. 2008; 105(52): 20705-20710. PubMed Abstract | Publisher Full Text | Free Full Text

29. Rainey PB, Travisano M: Adaptive radiation in a heterogeneous environment. Nature. 1998; 394(6688): 69-72.

PubMed Abstract | Publisher Full Text

30. Buckling A, Rainey PB: The role of parasites in sympatric and allopatric host diversification. Nature. 2002; 420(6915): 496-499. PubMed Abstract | Publisher Full Text

31. Clutton-Brock TH: Reproductive Effort and Terminal Investment in Iteroparous Animals. Am Nat. 1984; 123(2): 212-229. Publisher Full Text

32. Hochberg ME, Michalakis $\mathrm{Y}$, De Meeûs $\mathrm{T}$, et al:: Parasitism as a constraint on the rate of life-history evolution. J Evol Biol. 1992; 5(3): 491-504. Publisher Full Text

33. Michalakis $\mathrm{Y}$, Hochberg ME: Parasitic effects on host life-history traits: a review of recent studies. Parasite. 1994; 1(4): 291-294. PubMed Abstract

34. Mitchell SE, Rogers ES, Little TJ, et al.: Host-parasite and genotype-byenvironment interactions: temperature modifies potential for selection by a sterilizing pathogen. Evolution. 2005; 59(1): 70-80. PubMed Abstract | Publisher Full Text

35. Minchella DJ: Host life-history variation in response to parasitism. Parasitology. 1985; 90(1): 205-216.

Publisher Full Text

36. Lafferty KD: The marine snail, Cerithidea californica, matures at smaller sizes 
where parasitism is high. Oikos. 1993; 68(1): $3-11$ Reference Source

37. Adamo SA: Evidence for adaptive changes in egg laying in crickets exposed to bacteria and parasites. Anim Behav. 1999; 57(1): 117-124.

PubMed Abstract | Publisher Full Text

38. Blair L, Webster JP: Dose-dependent schistosome-induced mortality and morbidity risk elevates host reproductive effort. J Evol Biol. 2007; 20(1): 54-61. PubMed Abstract | Publisher Full Text

39. Chadwick W, Little TJ: A parasite-mediated life-history shift in Daphnia magna. Proc Biol Sci. 2005; 272(1562): 505-9.

PubMed Abstract | Publisher Full Text | Free Full Text

40. Chevin LM, Lande R, Mace GM: Adaptation, plasticity, and extinction in a changing environment: towards a predictive theory. PLOS Biol. 2010; 8(4): e1000357.

PubMed Abstract | Publisher Full Text | Free Full Text

41. Meyers LA, Bull JJ: Fighting change with change: adaptive variation in an uncertain world. Trends Ecol Evol. 2002; 17(12): 551-557. Publisher Full Text

42. Coustau C, Chevillon C, Ffrench-Constant R: Resistance to xenobiotics and parasites: can we count the cost? Trends Ecol Evol. 2000; 15(9): 378-383. PubMed Abstract | Publisher Full Text

43. Rigby MC, Hechinger RF, Stevens L: Why should parasite resistance be costly? Trends Parasitol. 2002; 18(3): 116-120. PubMed Abstract | Publisher Full Text

44. Buckling A, Wei Y, Massey RC, et al:: Antagonistic coevolution with parasites increases the cost of host deleterious mutations. Proc Biol Sci. 2006; 273(1582): 45-49.

PubMed Abstract | Publisher Full Text | Free Full Text

45. Heineman RH, Springman R, Bull JJ: Optimal foraging by bacteriophages through host avoidance. Am Nat. 2008; 171(4): E149-57.

PubMed Abstract | Publisher Full Text

46. Sibley MW, Cerdeño-Tárraga AM, Vernikos GS, et al:: Genomic and genetic analyses of diversity and plant interactions of Pseudomonas fluorescens. Genome Biol. 2009; 10(5): R51.

PubMed Abstract | Publisher Full Text | Free Full Text

47. Nechaev S, Severinov K: The elusive object of desire--interactions of bacteriophages and their hosts. Curr Opin Microbiol. 2008; 11(2): 186-193. PubMed Abstract | Publisher Full Text | Free Full Text

48. Rabinovitch A, Fishov I, Hadas $\mathrm{H}$, et al:: Bacteriophage T4 development in Escherichia coli is growth rate dependent. $J$ Theor Biol. 2002; 216(1): 1-4. PubMed Abstract | Publisher Full Text

49. Escobar-Paramo P, Faivre N, Buckling A, et al:: Persistence of costly novel genes in the absence of positive selection. J Evol Biol. 2009; 22(3): 536-543. PubMed Abstract | Publisher Full Text

50. Ryter A, Shuman H, Schwartz M: Intergration of the receptor for bacteriophage lambda in the outer membrane of Escherichia coli: coupling with cell division. J Bacteriol. 1975; 122(1): 295-301. PubMed Abstract | Free Full Text

51. Zeng L, Skinner SO, Zong C, et al:: Decision making at a subcellular level determines the outcome of bacteriophage infection. Cell. 2010; 141(4): 682-691.

PubMed Abstract | Publisher Full Text | Free Full Text

52. Lee K, Hahne F, Sarkar D, et al:: iFlow: A Graphical User Interface for Flow Cytometry Tools in Bioconductor. Adv Bioinformatics. 2009; 103839. PubMed Abstract | Publisher Full Text | Free Full Text

53. R Development Core Team: R: A Language and Environment for Statistical Computing. 2009; 409.

Reference Source 


\title{
Open Peer Review
}

\section{Current Peer Review Status: ? ?}

\section{Version 1}

Reviewer Report 22 October 2012

https://doi.org/10.5256/f1000research.121.r458

(C) 2012 Turner P. This is an open access peer review report distributed under the terms of the Creative Commons Attribution License, which permits unrestricted use, distribution, and reproduction in any medium, provided the original work is properly cited.

\author{
Paul E. Turner \\ Department of Ecology and Evolutionary Biology, Yale University, New Haven, CT, USA
}

1. Is there a subpopulation of the UV inactivated phage that are destroyed in the process of creating them, such that addition to bacterial cultures might constitute addition of DNA that can be taken up through transformation ? If so, is it possible that this transformed DNA is being used as a nutrient by the bacteria? This might explain the slight increase in growth rate of phageexposed bacteria in the experiments. There is precedent in other bacterial systems, but I do not know whether this provides an alternative explanation in the current study. The authors should take this possibility into account.

2. It is unclear what constitutes the controls performed in this study. One choice of control would be to obtain the UV-inactivated phage, and then remove these particles via centrifugation. The particle-free supernatant would then be added to controls, so that all components (except phage presence) would be otherwise identical across treatments and controls. However, it is unclear whether this was the approach used, and therefore I am worried that the chosen control is insufficient for drawing proper conclusions in the work.

Overall, the work seems very preliminary, and the data presented are not strongly supportive of the conclusions drawn.

Competing Interests: No competing interests were disclosed.

I confirm that I have read this submission and believe that I have an appropriate level of expertise to confirm that it is of an acceptable scientific standard, however I have significant reservations, as outlined above.

Reviewer Report 08 October 2012

https://doi.org/10.5256/f1000research.121.r457 
(C) 2012 Koskella B. This is an open access peer review report distributed under the terms of the Creative Commons Attribution License, which permits unrestricted use, distribution, and reproduction in any medium, provided the original work is properly cited.

\section{Britt Koskella}

Centre for Ecology \& Conservation Biosciences, College of Life \& Environmental Sciences, University of Exeter, Exeter, UK

Understanding the response of bacterial populations to bacteriophage viruses is of central importance to predicting microbial dynamics. To do so requires knowledge about both the ecological and evolutionary responses of bacteria to phage in the environment.

This includes possible changes in bacterial growth rate and cell size, as both have been shown to affect the rate of adsorption of phages by host cells (e.g. Hadas et al. 1997). In this paper, Poisot and coauthors investigate the inducible response of bacteria to phages by using UV-treated phages that are capable of binding to, but not infecting their host cells. They find that bacteria encountering UV-treated phages have a faster doubling time and smaller cell size than the control bacterial populations but that this response is short-lived and does not confer resistance to the phage.

This is a very intriguing result that confirms work from studies using live phages (e.g. Gómez, P. and A. Buckling. 2011) and suggests that binding of phages, regardless of subsequent infection success, might play a key role in shaping bacterial population dynamics. The approach taken is a very nice way to look for inducible responses to phage and the results are, for the most part, very clear. I do, however, wonder about the independence of the results for doubling time (measured as optical density) and cell size. Surely the optical density measure is affected by the cell size? The authors state that "Analyses of the distribution of several flow cytometry profiles showed that a difference in cell shape is unlikely to explain this result (see data associated to this article)" Since this is an absolutely central result of the finding, I would find it very helpful if the authors actually presented and discussed this evidence. In fact, it was not clear to me which data were in support of this. Otherwise, I do not think that the results should be used to primarily suggest a phageinduced response of increased growth rate, with a cost of decreased cell size. Instead, perhaps it is a response of decreased cell size with a subsequent small change in doubling time? I imagine the authors have the analyses to rule out the latter possibility. Further to this, when the authors do look directly at colony forming units, rather than optical density, in their analyses of bacterial resistance to live phages they do not find a difference among the treatments. In this case, when bacteria were exposed to live phages, bacterial populations that had been exposed to inactivated phages grew to the same densities over 24 hours as those that had not been exposed to inactivated phages. I find this hard to interpret as it could suggest that a) the previous results were primarily indicative of a change in cell size, rather than growth rate, or even that b) the bacteria from the inactivated phage treatments do have a higher growth rate but were more susceptible to phages and thus had the same CFU. It would be helpful if the authors could discuss this result in more detail.

I have a few additional points of clarification that I think would help readers fully understand the results. 
First, I wonder whether the authors could clarify their thoughts on the mechanism underlying the change to smaller cell size and/or increased doubling time of bacteria encountering inactivated phages. For example, could it be that small cell size is a response to altered numbers or activity of receptors on the bacterial cell surface? It seems that phage binding to receptors could alter their function and thus those bacterial cells with bound inactivated phages could be smaller due to decreased uptake of resources.

Second, I think the finding that bacteria treated with inactivated phages show changes in growth rate and/or cell size but do not differ in terms of their resistance to live phages is quite interesting! I would be keen to know what the infection rates of the control and treated populations were, as this would help with interpretation of the result. It seems surprising that there is no change in resistance, as previous evidence suggests a strong correlation between cell size and growth rate with adsorption rate. Might this result give insight to the mechanism underlying the changes observed? The authors mention that smaller surface area would mean a lower encounter rate with phages, but this doesn't seem to be the case when the cells are exposed to live phages.

As a very minor point, I wonder whether the authors meant to say that bacteria were separated from unbound, rather than bound, phages in their methods section, as it is unclear how centrifugation would separate bacteria from bound phages.

Competing Interests: No competing interests were disclosed.

\section{I confirm that I have read this submission and believe that I have an appropriate level of expertise to confirm that it is of an acceptable scientific standard, however I have significant reservations, as outlined above.}

The benefits of publishing with F1000Research:

- Your article is published within days, with no editorial bias

- You can publish traditional articles, null/negative results, case reports, data notes and more

- The peer review process is transparent and collaborative

- Your article is indexed in PubMed after passing peer review

- Dedicated customer support at every stage

For pre-submission enquiries, contact research@f1000.com 